Article

\title{
The Post-Ovariectomy Interval Affects the Antidepressant-Like Action of Citalopram Combined with Ethynyl-Estradiol in the Forced Swim Test in Middle Aged Rats
}

\author{
Nelly M. Vega Rivera ${ }^{1}$, Alfredo Gallardo Tenorio ${ }^{2}$, Alonso Fernández-Guasti ${ }^{2}$ and $^{1}$ \\ Erika Estrada Camarena ${ }^{1, *}$ \\ 1 Neuropsicofarmacología, Dirección de Neurociencias, Instituto Nacional de Psiquiatría “Ramón de la \\ Fuente Muñiz", INPRFM, Calzada México-Xochimilco 101, Col San Lorenzo Huipulco 14370, Mexico; \\ vegquim2909@hotmail.com \\ 2 Departamento de Farmacobiología, Centro de Investigación y Estudios Avanzados-Sede Sur. IPN, \\ Calzada de los Tenorios 235, Col Granjas Coapa 14330, Mexico; alfie_891@hotmail.com (A.G.T.); \\ jfernand@cinvestav.mx (A.F.-G.) \\ * Correspondence: estrada@imp.edu.mx; Tel.: +52-55-41605053
}

Academic Editor: Guy Griebel

Received: 31 December 2015; Accepted: 18 April 2016; Published: 3 May 2016

\begin{abstract}
The use of a combined therapy with low doses of estrogens plus antidepressants to treat depression associated to perimenopause could be advantageous. However the use of these combinations is controversial due to several factors, including the time of intervention in relation to menopause onset. This paper analyzes whether time post-OVX influences the antidepressant-like action of a combination of ethynyl-estradiol ( $\left.\mathrm{EE}_{2}\right)$ and citalopram (CIT) in the forced swim test (FST). Middle-aged (15 months old) female Wistar rats were ovariectomized and after one or three weeks treated with $\mathrm{EE}_{2}(1.25,2.5$ or $5.0 \mu \mathrm{g} / \mathrm{rat}$, s.c.; $-48 \mathrm{~h})$ or CIT $(1.25,2.5,5.0$ or $10 \mathrm{mg} / \mathrm{kg}$, i.p./3 injections in $24 \mathrm{~h}$ ) and tested in the FST. In a second experiment, after one or three weeks of OVX, rats received a combination of an ineffective dose of $\mathrm{EE}_{2}(1.25 \mu \mathrm{g} / \mathrm{rat}$, s.c., $-48 \mathrm{~h})$ plus CIT $(2.5 \mathrm{mg} / \mathrm{kg}$, i.p./3 injections in $24 \mathrm{~h}$ ) and subjected to the FST. Finally, the uteri were removed and weighted to obtain an index of the peripheral effects of $\mathrm{EE}_{2}$ administration. $\mathrm{EE}_{2}(2.5 \mathrm{or} 5.0 \mu \mathrm{g} / \mathrm{rat})$ reduced immobility after one but not three weeks of OVX. In contrast, no CIT dose reduced immobility at one or three weeks after OVX. When $\mathrm{EE}_{2}(1.25 \mu \mathrm{g} / \mathrm{rat})$ was combined with CIT $(2.5 \mathrm{mg} / \mathrm{kg})$ an antidepressant-like effect was observed at one but not three weeks post-OVX. The weight of the uteri augmented when $\mathrm{EE}_{2}$ was administrated three weeks after OVX. The data suggest that the time post-OVX is a crucial factor that contributes to observe the antidepressant-like effect of $\mathrm{EE}_{2}$ alone or in combination with CIT.
\end{abstract}

Keywords: ethynyl-estradiol; citalopram; forced swim test; post-OVX interval; perimenopause; antidepressant-like effect

\section{Introduction}

Women report more depression than men (by a factor of 2:1), particularly associated with their reproductive life span [1]. In fact, the onset or exacerbation of depressive symptoms has been associated to perimenopause [2,3]. Some reports indicate that the antidepressant response could be modified by the endocrine condition, since premenopausic women are more responsive than post-menopausic females [4-6]. However, other reports do not show differences in the response to antidepressants during the perimenopause transition $[7,8]$. Important methodological differences could contribute 
to explain these controversial results; for example, the time of intervention in relation to menopause onset, called the "critical period" $[9,10]$ as well as whether menopause is natural or induced. In this line, recent reports suggest that an opportune intervention during early menopause is more effective than during late-menopause [11-15]. However, Henderson and Popat [16] in a systematic review, reported that the literature is not enough to support or decline this hypothesis.

Estrogen replacement therapy (ERT) is an effective treatment for depression associated to perimenopause, along with its beneficial effects on other climacteric symptoms like osteoporosis and hot flashes [17]. The use of a combined therapy of antidepressants plus ERT to treat depression and climacteric symptoms seems useful. For example, ERT may shorten the onset of the therapeutic effects of antidepressants [5,18-20] and may reduce vasomotor symptoms, prevent osteoporosis and cardiovascular insults, as well as promoting neuroprotection [21-23]. However, controversial results have restricted their utilization $[17,24]$, among them the efficacy of ERT to reduce depression $[8,25]$ versus their putative adverse effects. For example, the combined use of ERT plus antidepressants has been related to a higher risk of developing cancer, particularly in long-term users and in women with a history of breast cancer [26,27]. In contrast, short-term treatment with a low-dose of conjugated equine estrogens and fluvoxamine is effective and safe for oophorectomized women in relieving hot flashes and depression [28]. Preclinical data in models that have predictive value, using young rats and at a constant post-OVX interval, showed that estrogens shorten and potentiate the antidepressant-like action of selective serotonin reuptake inhibitors (SSRIs) [21,29]. However there are no studies exploring whether age and the post-OVX interval modify the antidepressant-like action of the combination of estrogens and antidepressants.

Interestingly, the antidepressant-like effects of estrogens appear to depend on both the age and post-OVX interval [30-33]. For instance, 5 or $10 \mu \mathrm{g} / \mathrm{rat}$ of $17 \beta$-estradiol ( $\left.\mathrm{E}_{2}\right)$ produced an antidepressant-like action in 3 month old OVX rats, while in 15 month old rats, only $10 \mu \mathrm{g} / \mathrm{rat}$ had an effect; suggesting that $\mathrm{E}_{2}$ sensitivity decreases with age [34]. Furthermore, no action was reported in senescent rats [30,31]. Interestingly, aging also abbreviates the intervention window with $\mathrm{E}_{2}$, since the point of restitution in relation to time after OVX is three months after OVX in young rats, while in aged rats it is restricted to one week [13,32-34]. The action of antidepressants is also modulated by age, because their effect decreases in middle-age rats and may vanish at senescence [34-36].

Therefore, the aim of the present study was to explore whether the post-OVX interval influences the antidepressant-like action of $17 \alpha$-ethynyl estradiol $\left(\mathrm{EE}_{2}\right)$ and citalopram (CIT) alone or in combination in the forced swim test in rats aged 15 months. As an index of $\mathrm{EE}_{2}$ 's activity in peripheral tissues, the uterus weight was evaluated [32,37]. Citalopram was chosen because of its wide use in clinical practice due to less pharmacokinetic interactions with other drugs [38,39], particularly in middle-aged women that frequently consume several drugs [23]. EE 2 was selected because it is an estrogen commonly used in ERT, is more potent than $\mathrm{E}_{2}$ in reducing immobility behavior in the FST [40] and possesses a wider window of effect in the FST after OVX [32].

\section{Results}

\subsection{Experiment 1: Effect of Post-OVX Interval on the Effect of EE 2 or CIT in Middle-Aged Rats on the FST}

Figure 1 shows the effect of several $\mathrm{EE}_{2}$ doses (panel $\mathrm{A}$ ) administered 1 or 3 weeks post-surgery on behavioral immobility in the FST. The two-way analysis of variance indicated differences for the factor time $[\mathrm{F}(1,51)=23.81, p<0.001]$ and dose of $\mathrm{EE}_{2}[\mathrm{~F}(3,51)=4.23, p=0.009]$ without a significant interaction between them $[\mathrm{F}(3,51)=1.25, \mathrm{~ns}]$. Post-hoc comparisons revealed that at 1 week post-OVX (Panel A), $\mathrm{EE}_{2}$ reduced the immobility behavior compared to the control group at doses of $2.5 \mu \mathrm{g} / \mathrm{kg}$ $(p=0.008)$ or $5.0 \mu \mathrm{g} / \mathrm{kg}(p=0.04)$. However, at 3 weeks after OVX, no dose of $\mathrm{EE}_{2}$ induced changes on immobility. Differences between one and three weeks were observed at the doses of 2.5 or $5.0 \mu \mathrm{g} / \mathrm{kg}$ $(p=0.002$ and $p=0.001$, respectively). 


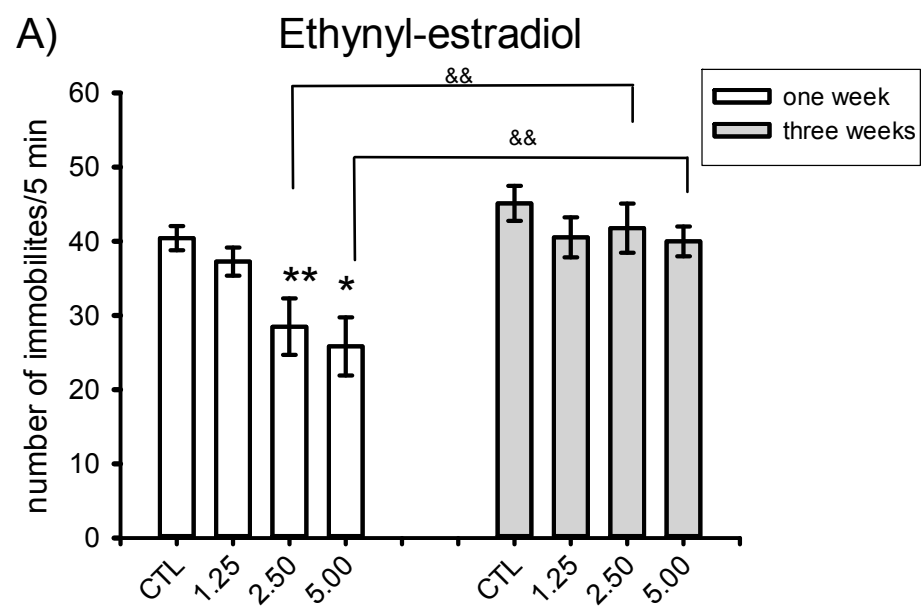

B) Citalopram

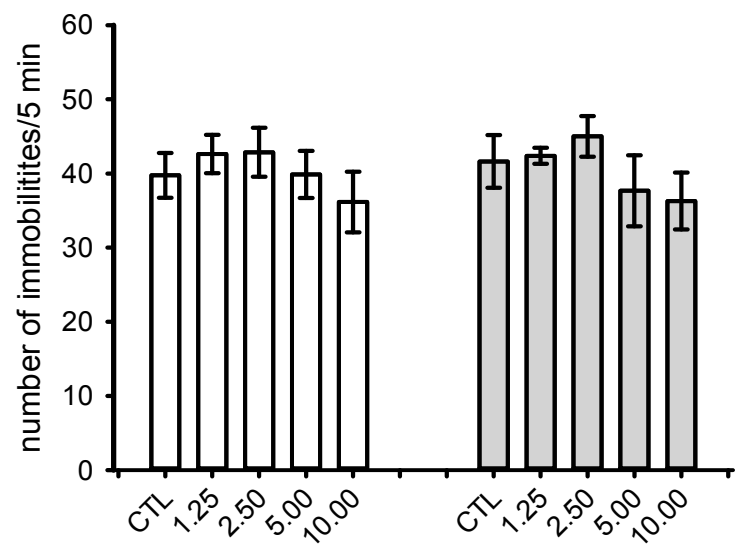

Figure 1. (A) Effect of ethynyl estradiol (1.25, 2.5 or $5 \mu \mathrm{g} / \mathrm{rat}$; $-48 \mathrm{~h}$ before the test; $n=7-9$ per group); and (B) citalopram $(1.25,2.5 ; 5.0$ or $10 \mathrm{mg} / \mathrm{kg} ;-23,-5,-1 \mathrm{~h}$ before the test; $n=6-8$ per group) at one or three weeks after ovariectomy in the forced swim test. The data represent the mean \pm S.E.M. of the number of immobilities scored in intervals of 5-s during a 5-min test session. Holm-Sidack test ${ }^{*} p<0.05 ;{ }^{* *} p<0.005$ versus respective control group; \&\& $p<0.005$ versus three weeks.

Figure 1B shows that no CIT dose tested reduced immobility at one or three weeks after OVX. The two-way analysis of variance showed no significant effect of time $[\mathrm{F}(1,63)=0.02$, ns]; dose of CIT $[\mathrm{F}(4,63)=1.64, \mathrm{~ns}]$ or the interaction between these factors $[\mathrm{F}(4,63)=0.14, \mathrm{~ns}]$.

Table 1 shows the effect of $\mathrm{EE}_{2}$ or CIT on the active behaviors scored in the FST. $\mathrm{EE}_{2}$, at $5.0 \mu \mathrm{g} / \mathrm{rat}$, increased swimming only one week after $\operatorname{OVX}(p<0.001)$. This increase differed from the value of the control group and the group treated with $\mathrm{EE}_{2}$ at this dose but tested three weeks post-OVX $(p<0.001)$. The two way ANOVA values for swimming behavior were: time post-OVX $[\mathrm{F}(1,54)=21.76$, $p<0.001]$, treatment $[\mathrm{F}(3,54)=21.76, p=0.02]$ and the interaction $[\mathrm{F}(3,54)=4.18, p=0.01]$. No changes were observed in climbing behavior in response to $\mathrm{EE}_{2}$ treatment at any time post-OVX. Thus the two way ANOVA values for climbing behavior were: time post-OVX $[\mathrm{F}(1,54)=1.78, \mathrm{~ns}]$, treatment $[\mathrm{F}(3,54)=0.98, \mathrm{~ns}]$ and their interaction $[\mathrm{F}(3,54)=2.45, \mathrm{~ns}]$. On the other hand, no CIT dose changed swimming or climbing behavior at any time post-OVX. 
Table 1. Effect of ethynyl-estradiol $\left(\mathrm{EE}_{2}\right)$ or citalopram (CIT) on the number (\#) of counts of swimming and climbing behavior scored in the forced swim test after one or three weeks post-OVX.

\begin{tabular}{|c|c|c|c|}
\hline Treatment & Post-OVX Interval & \# of Counts of Swimming & \# of Counts of Climbing \\
\hline Oil & & $9.3 \pm 1.4$ & $9.2 \pm 1.0$ \\
\hline EE2 $1.25(\mu \mathrm{g} / \mathrm{rat})$ & & $13.5 \pm 1.6$ & $9.1 \pm 2.0$ \\
\hline EE2 $2.5(\mu \mathrm{g} / \mathrm{rat})$ & & $19.0 \pm 3.9$ & $12.5 \pm 1.8$ \\
\hline EE2 $5.0(\mu \mathrm{g} / \mathrm{rat})$ & & $27.1 \pm 4.4^{* *}, \# \#$ & $7.0 \pm 2.1$ \\
\hline $\mathrm{SAL}^{+}$ & One Week & $9.3 \pm 1.4$ & $10.8 \pm 2.6$ \\
\hline CIT 1.25 & & $10.3 \pm 1.5$ & $7.0 \pm 1.6$ \\
\hline CIT 2.5 & & $10.7 \pm 3.3$ & $6.4 \pm 0.7$ \\
\hline CIT 5.0 & & $12.0 \pm 3.0$ & $8.1 \pm 1.2$ \\
\hline CIT 10 & & $17.0 \pm 3.5$ & $6.8 \pm 1.4$ \\
\hline OIL & & $11.3 \pm 2.4$ & $10.0 \pm 1.6$ \\
\hline EE2 1.25 & & $11.3 \pm 2.1$ & $8.1 \pm 1.2$ \\
\hline EE 2.5 & & $10.3 \pm 2.0$ & $7.8 \pm 1.6$ \\
\hline EE2 5.0 & & $9.1 \pm 1.8$ & $10.8 \pm 2.0$ \\
\hline SAL & Three Weeks & $10.5 \pm 1.8$ & $9.7 \pm 2.4$ \\
\hline CIT 1.25 & & $7.8 \pm 1.8$ & $9.7 \pm 2.4$ \\
\hline CIT 2.5 & & $9.3 \pm 2.3$ & $5.6 \pm 1.2$ \\
\hline CIT 5.0 & & $16.5 \pm 3.9$ & $5.8 \pm 2.1$ \\
\hline CIT 10 & & $12.2 \pm 2.0$ & $11.4 \pm 3.2$ \\
\hline
\end{tabular}

The data are shown as mean \pm S.E.M of the number of counts for swimming and climbing behaviors scored in 5 -sec intervals in a 5-min session of forced swimming. ${ }^{\dagger} \mathrm{SAL}=$ saline. Holm-Sidack test; ${ }^{* *} p<0.001$ versus the control group; ${ }^{\#} p<0.001$ versus three weeks.

Table 2 shows the weight of uteri in 15 month old rats treated with different doses of $\mathrm{EE}_{2}(1.25,2.5$ or $5.0 \mu \mathrm{g} / \mathrm{rat}$, s.c. -48 before FST) at one or three weeks post-OVX. The uteri from rats treated acutely with oil three weeks after surgery were lighter than those from rats treated with oil after one week $(p=0.03)$. The groups that received $\mathrm{EE}_{2}$ at one week post-OVX did not show significant changes in their uteri weight. In contrast, the groups that received a single dose of $\mathrm{EE}_{2}$ at $2.5 \mathrm{or} 5.0 \mu \mathrm{g} / \mathrm{rat}$ had significantly increased uteri weight compared to the control group $(p<0.05)$ and to the groups that received the same dose one week after OVX $(p<0.001)$. The two-way ANOVA revealed no significant differences for the factors time $[\mathrm{F}(1,23)=0.19, \mathrm{~ns}]$ or dose $[\mathrm{F}(3,23)=0.65, \mathrm{~ns}]$; however, a significant interaction between them was detected $[\mathrm{F}(3,23)=7.66, p<0.001]$.

Table 2. Effect of ethynyl-estradiol administration one or three weeks post-OVX on uterus weight (mg).

\begin{tabular}{ccc}
\hline Ethynyl-Estradiol $(\mu \mathrm{g} / \mathrm{rat})$ & One Week $(\boldsymbol{n}=\mathbf{4})$ & Three Weeks $(\boldsymbol{n}=\mathbf{4})$ \\
\hline OIL & $54.5 \pm 8.52$ & $34.5 \pm 4.97^{\&}$ \\
1.25 & $53.3 \pm 10.5$ & $50.6 \pm 1.45$ \\
2.5 & $40.5 \pm 3.42$ & $57.2 \pm 2.13^{*, \&}$ \\
5.0 & $36.0 \pm 5.52$ & $62.2 \pm 3.11^{*} \& \&$ \\
\hline
\end{tabular}

The data are presented as mean \pm S.E.M of the uterus weight of four rats per group. Holm-Sidack test ${ }^{*} p=0.05$ versus the control group; $\& p=0.05$, \&\& $p=0.005$ versus one week.

\subsection{Experiment 2: Effect of Post-OVX Interval on the Effect of the Combination of Non-Effective Doses of EE 2} plus CIT in Middle-Aged Rats on the FST

Figure 2 shows the effect of a combined low dose of $\mathrm{EE}_{2}(1.25 \mu \mathrm{g} / \mathrm{kg})$ and CIT $(2.5 \mathrm{mg} / \mathrm{kg})$ administered at one or three weeks post-OVX on the FST. EE 2 or CIT alone did not modify the immobility behavior in the FST at one or three weeks post-OVX. In contrast, the combination $\mathrm{EE}_{2}$ plus CIT tested one week after OVX decreased immobility compared to the control group $(p<0.05)$ and versus the same treatment at three weeks post-OVX $(p<0.001)$, when it failed to have an effect. The two-way ANOVA showed significant differences for time $[\mathrm{F}(1,51)=5.25, p=0.02]$; no significant 
disparity for treatment $[\mathrm{F}(3,51)=3.35, p=0.08]$ and a significant interaction between these factors $[\mathrm{F}(3,51)=2.77, p=0.05]$.

\section{Ethynyl-estradiol plus Citalopram}

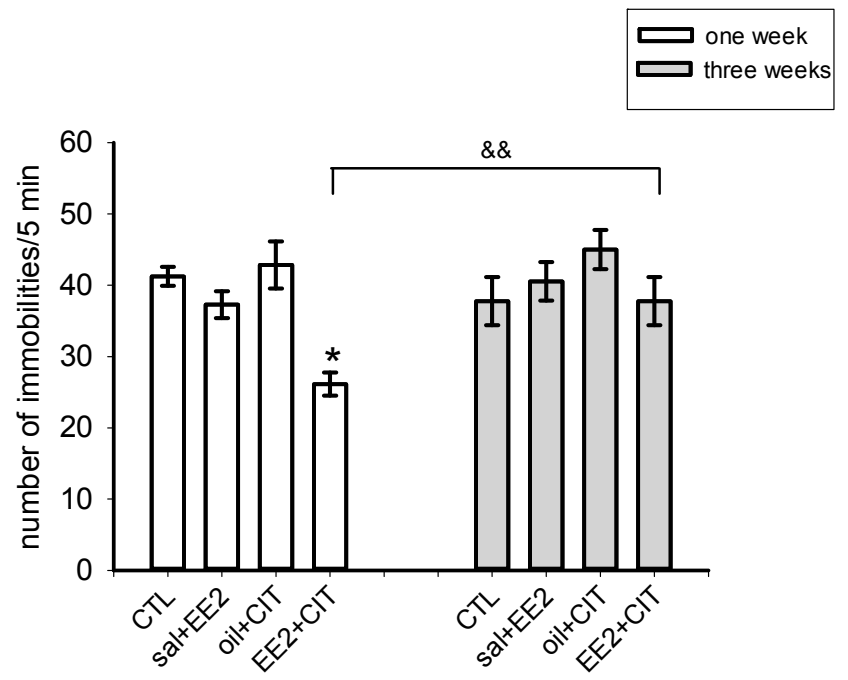

Figure 2. Effect of the combination of ethynyl estradiol $(2.5 \mu \mathrm{g} / \mathrm{rat} ;-48$ before the test $)$ plus citalopram ( $2.5 \mathrm{mg} / \mathrm{kg} ;-23,-5,-1 \mathrm{~h}$ before the test) at one ( $n=6-8$ per group) or three ( $n=6-8$ per group) weeks after ovariectomy in the forced swim test. The data represent the mean \pm S.E.M of the number of scored immobilities in intervals of 5-s during a 5-min test session. Holm-Sidack test ${ }^{*} p<0.05$ versus respective control group; \&\& $p<0.005$ versus three weeks.

Table 3 shows the effect of the combination of low doses of $\mathrm{EE}_{2}$ plus CIT on swimming and climbing scored in the FST. $E_{2}$ in combination with CIT increased swimming at one, but not at three, weeks post-OVX compared to the control group and the group treated three weeks after OVX. The two way ANOVA yielded the following values for time post-OVX $[\mathrm{F}(3,51)=2.47, p=0.07]$; treatment $[\mathrm{F}(1,51)=2.48, p=0.09]$ and their interaction $[\mathrm{F}(3,51)=5.50, p=0.002]$. No significant changes were observed on climbing behavior in response to $\mathrm{EE}_{2}$ plus CIT.

Table 3. Effect of the combination of ethynyl-estradiol plus citalopram on the number of counts of swimming and climbing behaviors scored in the forced swim test after one or three weeks post-OVX.

\begin{tabular}{cccc}
\hline Treatment & Time Post-OVX & Swimming & Climbing \\
\hline OIL/SAL & & $8.3 \pm 0.68$ & $10.1 \pm 1.5$ \\
EE2 $(1.25 \mu \mathrm{g} / \mathrm{rat})$ & One Week & $13.5 \pm 1.6$ & $9.1 \pm 2.0$ \\
CIT $(2.5 \mathrm{mg} / \mathrm{kg})$ & & $10.7 \pm 3.3$ & $6.4 \pm 0.7$ \\
EE2/CIT & & $24.8 \pm 2.5^{* *, \# \#}$ & $9.0 \pm 2.6$ \\
\hline OIL/SAL & & $14.2 \pm 2.5$ & $8.0 \pm 1.8$ \\
EE2 (1.25 $\mu \mathrm{g} / \mathrm{rat})$ & Three Weeks & $11.3 \pm 2.1$ & $8.1 \pm 1.2$ \\
CIT $(2.5 \mathrm{mg} / \mathrm{kg})$ & & $9.3 \pm 2.3$ & $9.7 \pm 2.4$ \\
EE2 $/ \mathrm{CIT}$ & & $9.8 \pm 2.6$ & $7.1 \pm 1.4$
\end{tabular}

The data are presented as mean \pm S.E.M of the number of counts for swimming and climbing scored in 5 -sec intervals in a 5-min session of forced swimming. Holm-Sidack test ${ }^{* *} p<0.001$ versus the control group; \#\# $p<0.001$ versus three weeks.

\section{Discussion}

The antidepressant-like action of $\mathrm{EE}_{2}$, in contrast to that of CIT, depends on the post-OVX interval. Remarkably, the combination of a non-effective dose of $\mathrm{EE}_{2}$ plus CIT promotes an antidepressant-like action in the FST only one week post-OVX. In middle-aged female rats, the antidepressant-like effect 
of $\mathrm{EE}_{2}$ was observed at one but not at three weeks post-OVX. These results are partially in line with previous data showing that ERT produces an antidepressant-like effect in FST if given closer to the estrogen decline [30,32]. However, the present findings are in contrast with a previous report where $\mathrm{EE}_{2}$ exerted an antidepressant-like effect in the FST after twelve weeks of OVX [32]. An explanation for this divergence is the age of the females: young ( 3 months) versus middle-aged ( 15 months) rats. In support, some reports indicate that ovariectomized young ( 3 months) and adult (7 months) rats are more responsive to $E_{2}$ restitution than middle-aged animals (12 months) [30,31]. At the age of twelve months none of the female rats shows regular estrous cycles most have irregular cycles and a few show persistent estrus or diestrus [41-43]. After reproductive senescence, there could be an adjustment in estrogen receptor sensitivity [44-46] that affects the critical period for an intervention with estrogens. Importantly, most studies perform OVX before periestropause and evaluate the critical window for intervention considering the period of estrogen decline $[12,33,45,47]$, but not the age at which OVX is performed. In this sense, recently García et al. [47] showed that changes in the expression of genes involved in social and affiliative behaviors-such as vasopressin and oxitocin-varied according to the age when OVX was performed as well as the interval after OVX.

CIT lacked an effect on the FST independently of the post-OVX interval. Several reports indicate that CIT produces an antidepressant-like effect in the FST [48,49]; however these studies were performed in 3 month old rats. It could be argued that the doses we tested were insufficient to promote an antidepressant-like effect. However, Flores Serrano et al. [48] showed that CIT reduced immobility on the FST at doses of 1 or $3 \mathrm{mg} / \mathrm{kg}$, in 2-3 month old female rats independently of the estrous cycle. In the present study, doses in the range of 1.25 to $10 \mathrm{mg} / \mathrm{kg}$ had no action, making it unlikely that a dose-related problem explains the absence of an effect. Most likely, age and endocrine condition are factors that contribute to decrease the sensitivity to CIT. A similar result was reported by Olivares-Nazario et al. [35] who showed that senescent (23-25 months) male rats did not respond to the antidepressant-like effect of desimipramine or fluoxetine in the FST. In contrast, middle-aged females (14 to 18 month old), subjected to the chronic mild stress depression model, showed a transitory antidepressant-like effect of $10 \mathrm{mg} / \mathrm{kg}$ CIT [50]. Differences in the model and treatment schedule (chronic versus sub-acute) could contribute to the divergent results. However, the transitory effect of CIT in the chronic mild stress paradigm [50] suggests some degree of age-dependent insensitivity.

CIT is a highly selective serotonin transporter (SERT) inhibitor [49]. A previous study showed that SERT expression increased in response to stress by FST in young but not in middle-aged rats [51]. Indeed, studies in non-human primates have shown that aging is associated with decreased specific SERT binding [52]. Accordingly, it is possible that CIT lacked an antidepressant-like effect due to reduced SERT sensitivity caused by aging [53] and the endocrine condition. Supporting this notion, the present study showed that the combination of a non-effective dose of $\mathrm{EE}_{2}$ plus a low dose of CIT produced an antidepressant-like action after one week of OVX, suggesting that $\mathrm{EE}_{2}$ modulates SERT activity. In agreement, earlier reports indicated that the activity and affinity of SERT are modulated by estrogens, such as $\mathrm{EE}_{2}$ [54-56], even in males. Interestingly, the antidepressant-like action of $\mathrm{EE}_{2}$ requires presynaptic elements, possibly the SERT [57].

Alternatively, the combination of $\mathrm{EE}_{2}$ plus CIT maybe is effective one week after OVX because $\mathrm{EE}_{2}$ acts at estrogen receptors, which indirectly modulate the serotonergic system through 5-HT1A receptors [57-59]. The present data agree with a previous report showing that the combination of $\mathrm{EE}_{2}$ plus a SSRI mainly affected swimming behavior [49], which is regulated by the serotonergic system [60].

Importantly, the modulation that $\mathrm{EE}_{2}$ exerts on the effect of CIT has a critical period after which it is ineffective. The factors that underlie this response are unknown; however, it has been reported that estradiol requires the ER $\alpha$-mGlutR1, PI3K/Akt and MAPK/ERK1/2 pathways to modulate the activity of SSRIs on the SERT [61]. Interestingly, ER $\alpha$ loses sensitivity with aging in the same manner than SERT $[44,45,51,53]$. Furthermore, ER $\alpha$-IGF-R1 sensitivity decreased with aging if an intervention with estradiol did not occur close to OVX [62]. Consequently, it is feasible to consider that both age 
and time after OVX contribute to explain the lack of sensitivity of females after three weeks of OVX. Taken together it is possible that a complex mechanism of action, which requires further examination, underlies the antidepressant-like action of $\mathrm{EE}_{2}$ alone and in combination with CIT.

$\mathrm{EE}_{2}$ increased the weight of uteri even though it lacked an effect on the FST. The present data suggest that the beneficial effect of estrogens on the brain is restricted to a specific period close to the natural decline of estrogen levels and this is independent of the peripheral effect of estrogens on different tissues. A shortcoming of the present data is the absence of histological analyses to evaluate the structural changes induced by $\mathrm{EE}_{2}$ in the uterus. Furthermore, the differences in the weight of uteri between control groups could be explained by the stimulatory effect of the remaining hormones after OVX. Thus, one week post-OVX, the control uteri were heavier than those obtained after three weeks and in the former $\mathrm{EE}_{2}$ did not modify their weight at any dose tested. In contrast, after three weeks, acute $\mathrm{EE}_{2}$ administration increased their weight to control values, suggesting that $\mathrm{EE}_{2}$ has a physiological action. Specific experiments to analyze a putative stimulatory effect of $\mathrm{EE}_{2}$ on uterus weight are warranted.

\section{Material and Methods}

\subsection{Animals}

Female Wistar rats of 15 months were group-housed (five to six per cage) in polycarbonate cages. All animals had free access to food and water. They were maintained on a 12:12-h light:dark cycle with lights on at 10:00 $\mathrm{h}$ and a room temperature of $23 \pm 2{ }^{\circ} \mathrm{C}$. All procedures observed the Mexican Official Norm for animal care and handling (NOM-062-ZOO-1999) and were approved by the Local Institutional Ethics Committee.

\subsection{Ovariectomy}

In the present study all rats were ovariectomized (OVX) one or three weeks before behavioral assessments in order to simulate menopause [63-65]. A ventral incision was made to remove the ovaries in rats anesthetized with tribromoethanol (2\%; dose: $0.1 \mathrm{~mL} / \mathrm{kg}$. i.p.). Care was taken to totally excise the ovaries, which was corroborated by visual inspection. A recovery period of one or three weeks was allowed before rats were randomly assigned to the experimental groups [32].

\subsection{Drugs}

Citalopram clorhidrate (kindly donated by Psicofarma ${ }^{\circledR}$, México, México) was dissolved in physiological saline solution to prepared doses of $1.25,2.5,5.0$ or $10 \mathrm{mg} / \mathrm{kg}$ that were administered in a sub-acute schedule ( 3 injections / $-23,-5$ and $-1 \mathrm{~h}$ before FST) in a volume of $2 \mathrm{~mL} / \mathrm{kg}$. $17 \alpha$-ethynyl estradiol (Sigma-Aldrich, Toluca, México) was dissolved in corn oil and administered in a volume of $0.2 \mathrm{~mL} /$ rat $48 \mathrm{~h}$ before the FST at doses of $1.25,2.5$ or $5 \mu \mathrm{g} /$ rat. The drugs were freshly prepared. The doses and latencies were chosen from previous studies [40-63].

\subsection{Forced Swim Test}

The FST was conducted by placing rats inside individual Plexiglasscylinders (height: $46 \mathrm{~cm}$ and diameter: $20 \mathrm{~cm}$ ) filled with $30 \mathrm{~cm}$ of water at $23 \pm 2{ }^{\circ} \mathrm{C}$ [66-68]. Two swim sessions were conducted: a pretest of $15-\mathrm{min}$ followed $24 \mathrm{~h}$ later by a 5-min test, which was videotaped for scoring by an observer unaware of the treatments. After each swim session, rats were dried with a towel and placed in heated cages for $30 \mathrm{~min}$ before returning them to their home cages.

Three behavioral variables were scored during the test: (1) immobility, defined as the minimal movements done by the animal to keep its head above the water; (2) swimming, identified as gentle movements executed by the rat around the cylinder; and (3) climbing, characterized by vigorous movements of the forepaws directed against the wall of the cylinder $[40,67,68]$. 


\subsection{Experimental Design}

4.5.1. Experiment 1: Effect of Post-OVX Interval on the Effect of EE2 or CIT in Middle-Aged Rats on the FST

A dose-response curve for each compound was performed to determine the effective dose of $\mathrm{EE}_{2}$ or CIT to decrease immobility in middle-aged OVX rats. Independent groups were tested one or three weeks after the surgery; for CIT the groups were: saline, $1.25,2.5,5.0$ and $10 \mathrm{mg} / \mathrm{kg}(n=6-8$ per group) and for $\mathrm{EE}_{2}$ the groups included were: oil, 1.25, 2.5 and $5.0 \mu \mathrm{g} / \mathrm{rat}(n=7-9$ per group). CIT was administered $-23,-5$ and $-1 \mathrm{~h}$ before the FST. $\mathrm{EE}_{2}$ was dissolved in corn oil, prepared $72 \mathrm{~h}$ before its administration and injected acutely $-48 \mathrm{~h}$ before the behavioral test. Doses and latencies were taken from previous data $[29,36,65]$. At the end of the experiment six rats of each group that received $\mathrm{EE}_{2}$ were sacrificed and their uterus was removed, cleaned of fat and weighted in order to obtain an index of the peripheral effect of the steroid [32,37].

4.5.2. Experiment 2: Effect of Post-OVX Interval on the Effect of the Combination of Non-Effective Doses of EE2 Plus CIT in Middle-Aged Rats on the FST

In order to evaluate the effect of the post-OVX interval on the combination of $\mathrm{EE}_{2}$ plus CIT, independent groups of OVX rats received: oil/saline, $\mathrm{EE}_{2}(1.25 \mu \mathrm{g} / \mathrm{rat},-48 \mathrm{~h} / \mathrm{saline}), \mathrm{CIT}(2.5 \mathrm{mg} / \mathrm{kg}$; $-23,-5,-1 \mathrm{~h} / \mathrm{oil})$ and $\mathrm{EE}_{2}(1.25 \mu \mathrm{g} / \mathrm{rat} ;-48 \mathrm{~h})$ plus CIT $(2.5 \mathrm{mg} / \mathrm{kg} ;-23,-5,-1 \mathrm{~h})$. All groups were tested one ( $n=6-8$ per group) or three weeks ( $n=6-8$ per group) after OVX. The dose of EE 2 was established in experiment one. Due to the fact that all CIT doses assayed were ineffective in experiment one, the dose chosen for this experiment was $2.5 \mu \mathrm{g} /$ rat because other SSRIs are effective at this dose when combined with estrogens [21-29].

\subsection{Statistical Analysis}

The data are presented as mean \pm S.E.M. The data were analyzed using two-way analysis of variance considering time after OVX and treatment as factors. Holm-Sidack tests were used as a post-hoc method of paired comparison. In all cases a $p<0.05$ was considered significant.

\section{Conclusions}

In conclusion, the present data are in agreement with clinical reports showing that hormonal replacement therapy improves the effects of selective serotonin reuptake inhibitors in the post-menopausal condition $[69,70]$.Importantly, the time of $\mathrm{EE}_{2}$ restitution in relation to menopause should be considered in order to reach maximal beneficial effects and reduce the risk of adverse events.

Acknowledgments: The present study was partially supported by a grant to E-Estrada-Camarena from "Fundación Miguel Alemán". Authors thank to Bryan Phillips for his comments on the manuscript.

Author Contributions: E.E.C. and A.F.-G. conceived and designed the experiments; A.G.T. performed the experiments; N.M.V.R., E.E.C. and A.G.T. analyzed the data; E.E.C. and N.M.V.R. wrote the paper.

Conflicts of Interest: The authors declare no conflict of interest.

\section{References}

1. Fleiz Bautista, C.; Villatoro Velazquez, J.; Mora Icaza, M.E.; Moreno Lopez, M.; Gutierrez Lopez, M.D.L.; Oliva Robles, N. Sociodemographic and personal factors related to depressive symptomatology in the Mexican population aged 12 to 65. Rev. Brasil. Psiquiatr. 2012, 34, 395-404. [CrossRef]

2. Maki, P.M.; Freeman, E.W.; Greendale, G.A.; Henderson, V.W.; Newhouse, P.A.; Schmidt, P.J.; Scott, N.F.; Shively, C.A.; Soares, C.N. Summary of the National Institute on aging-sponsored conference on depressive symptoms and cognitive complaints in the menopausal transition. Menopause 2010, 17, 815-822. [CrossRef] [PubMed]

3. Soares, C.N. Depression in peri- and postmenopausal women: Prevalence, pathophysiology and pharmacological management. Drugs Aging 2013, 30, 677-685. [CrossRef] [PubMed] 
4. Huang, C.C.; Wei, I.H.; Chou, Y.H.; Su, T.P. Effect of age, gender, menopausal status, and ovarian hormonal level on rTMS in treatment-resistant depression. Psychoneuroendocrinology 2008, 33, 821-831. [CrossRef] [PubMed]

5. Soares, C.N.; Almeida, O.P.; Joffe, H.; Cohen, L.S. Efficacy of estradiol for the treatment of depressive disorders in perimenopausal women: A double-blind, randomized, placebo-controlled trial. Arch. Gen. Psychiatry 2001, 58, 529-534. [CrossRef] [PubMed]

6. Pae, C.U.; Mandelli, L.; Kim, T.S.; Han, C.; Masand, P.S.; Marks, D.M.; Patkar, A.A.; Steffens, D.C.; De Ronchi, D.; Serretti, A. Effectiveness of antidepressant treatments in pre-menopausal versus post-menopausal women: A pilot study on differential effects of sex hormones on antidepressant effects. Biomed. Pharmacother. 2009, 63, 228-235. [CrossRef] [PubMed]

7. Iglesias Garcia, C.; Ocio Leon, S.; Ortigosa Digon, J.C.; Merino Garcia, M.J.; Alonso Villa, M.J.; Fernandez Palicio, L.; Alonso Rionda, J.L.; Garcia Fernandez, F.; Rodriguez Colubi, L.; Toimil Iglesias, A. Comparison of the effectiveness of venlafaxine in peri- and postmenopausal patients with major depressive disorder. Actas Esp. Psiquiatr. 2010, 38, 326-331. [PubMed]

8. Kornstein, S.G.; Toups, M.; Rush, A.J.; Wisniewski, S.R.; Thase, M.E.; Luther, J.; Warden, D.; Fava, M.; Trivedi, M.H. Do menopausal status and use of hormone therapy affect antidepressant treatment response? Findings from the Sequenced Treatment Alternatives to Relieve Depression (STAR*D) study. J. Women's Health 2013, 22, 121-131. [CrossRef] [PubMed]

9. Sherwin, B.B. The critical period hypothesis: Can it explain discrepancies in the oestrogen-cognition literature? J. Neuroendocrinol. 2007, 19, 77-81. [CrossRef] [PubMed]

10. Rocca, W.A.; Grossardt, B.R.; Shuster, L.T. Oophorectomy, menopause, estrogen, and cognitive aging: The timing hypothesis. Neurodegener. Dis. 2010, 7, 163-166. [CrossRef] [PubMed]

11. Luine, V.N. Estradiol and cognitive function: Past, present and future. Horm. Behav. 2014, 66, 602-618. [CrossRef] [PubMed]

12. Smith, C.C.; Vedder, L.C.; Nelson, A.R.; Bredemann, T.R.; McMahon, L.R. Duration of estrogen deprivation, not chronological age, prevents estrogen's ability to enhance hippocampal synaptic physiology. Proc. Natl. Acad. Sci. USA 2010, 107, 19543-19548. [CrossRef] [PubMed]

13. Vedder, L.C.; Bredemann, T.M.; McMahon, L.L. Estradiol replacement extends the window of opportunity for hippocampal function. Neurobiol. Aging 2014, 35, 2183-2192. [CrossRef] [PubMed]

14. Thomas, J.; Météreau, E.; Déchaud, H.; Pugeat, M.; Dreher, J.C. Hormonal treatment increases the response of the reward system at the menopause transition: A counterbalanced randomized placebo-controlled fMRI study. Psychoneuroendocrinology 2014, 50, 167-180. [CrossRef] [PubMed]

15. Rocca, W.A.; Grossardt, B.R.; Geda, Y.E.; Gostout, B.S.; Bower, J.H.; Maraganore, D.M.; de Andrade, M.; Melton, L.J., III. Long-term risk of depressive and anxiety symptoms after early bilateral oophorectomy. Menopause 2008, 15, 1050-1059. [CrossRef]

16. Henderson, V.W.; Popat, R.A. Effects of endogenous and exogenous estrogen exposures in midlife and late-life women on episodic memory and executive functions. Neuroscience 2011, 5, 129-138. [CrossRef] [PubMed]

17. Rozenberg, S.; Vandromme, J.; Antoine, C. Postmenopausal hormone $\mathrm{t}$ herapy: Risks and benefits. Nat. Rev. Endocrinol. 2013, 9, 216-227. [CrossRef] [PubMed]

18. Rasgon, N.L.; Dunkin, J.; Fairbanks, L.; Altshuler, L.L.; Troung, C.; Elman, S.; Wroolie, T.E.; Brunhuber, M.V.; Rapkin, A. Estrogen and response to sertraline in postmenopausal women with major depressive disorder: A pilot study. J. Psychiatr. Res. 2007, 41, 338-343. [CrossRef] [PubMed]

19. Tam, L.W.; Parry, B.L. Does estrogen enhance the antidepressant effects of fluoxetine? J. Affect. Disord. 2003, 77, 87-92.

20. Schneider, L.S.; Small, G.W.; Clary, C.M. Estrogen replacement therapy and antidepressant response to sertraline in older depressed women. Am. J. Geriatr. Psychiatry 2001, 9, 393-399. [CrossRef] [PubMed]

21. Estrada-Camarena, E.; Rivera, N.M.; Berlanga, C.; Fernandez-Guasti, A. Reduction in the latency of action of antidepressants by $17 \beta$-estradiol in the forced swimming test. Psychopharmacology 2008, 201, 351-360. [CrossRef] [PubMed]

22. Studd, J. "PROFOX"-The post HRT nightmare. Climacter. J. Int. Menopause Soc. 2011, 14, 217-219. [CrossRef] [PubMed] 
23. Handley, A.P.; Williams, M. The efficacy and tolerability of SSRI/SNRIs in the treatment of vasomotor symptoms in menopausal women: A systematic review. J. Am. Assoc. Nurse Pract. 2015, 27, 54-61. [CrossRef] [PubMed]

24. Studd, J.; Nappi, R.E. Reproductive depression. Gynecol. Endocrinol. 2012, 28 (Suppl. S1), 42-45. [CrossRef] [PubMed]

25. Amsterdam, J.; Garcia-España, F.; Fawcett, J.; Quitkin, F.; Reimherr, F.; Rosenbaum, J.; Beasley, C. Fluoxetine efficacy in menopausal women with and without estrogen replacement. J. Affect. Disord. 1999, 55, 11-17. [CrossRef]

26. Soares, C.N.; Maki, P.M. Menopausal transition, mood, and cognition: An integrated view to close the gaps. Menopause 2010, 17, 812-814. [CrossRef] [PubMed]

27. Chlebowski, R.T.; Anderson, G.L. Changing concepts: Menopausal hormone therapy and breast cancer. J. Natl. Cancer Inst. 2012, 104, 517-527. [CrossRef] [PubMed]

28. Nagata, H.; Nozaki, M.; Nakano, H. Short-term combinational therapy of low-dose estrogen with selective serotonin re-uptake inhibitor (fluvoxamine) for oophorectomized women with hot flashes and depressive tendencies. J. Obst. Gynaecol. Res. 2005, 31, 107-114. [CrossRef] [PubMed]

29. Estrada-Camarena, E.; Fernandez-Guasti, A.; Lopez-Rubalcava, C. Interaction between estrogens and antidepressants in the forced swimming test in rats. Psychopharmacology 2004, 173, 139-145. [CrossRef] [PubMed]

30. Kiss, A.; Delattre, A.M.; Pereira, S.I.; Carolino, R.G.; Szawka, R.E.; Anselmo-Franci, J.A.; Zanata, S.M.; Ferraz, A.C. 17 $\beta$-estradiol replacement in young, adult and middle-aged female ovariectomized rats promotes improvement of spatial reference memory and an antidepressant effect and alters monoamines and BDNF levels in memory- and depression-related brain areas. Behav. Brain Res. 2012, 227, 100-108. [CrossRef] [PubMed]

31. Diz-Chaves, Y.; Kwiatkowska-Naqvi, A.; Von Hulst, H.; Pernia, O.; Carrero, P.; Garcia-Segura, L.M. Behavioral effects of estradiol therapy in ovariectomized rats depend on the age when the treatment is initiated. Exp. Gerontol. 2012, 47, 93-99. [CrossRef] [PubMed]

32. Estrada-Camarena, E.; Lopez-Rubalcava, C.; Hernandez-Aragon, A.; Mejia-Mauries, S.; Picazo, O. Long-term ovariectomy modulates the antidepressant-like action of estrogens, but not of antidepressants. J. Psychopharmacol. 2011, 25, 1365-1377. [CrossRef] [PubMed]

33. Sunday, L.; Osuna, C.; Krause, D.N.; Duckles, S.P. Age alters cerebrovascular inflammation and effects of estrogen. Am. J. Physiol. Heart Circul. Physiol. 2007, 292, H2333-4H230. [CrossRef] [PubMed]

34. Estrada-Camarena, E.; Mejia-Mauries, S.; Vega-Rivera, N.M.; Gallardo-Tenorio, A.; Fernández-Guasti, A. Use of combined therapy of estrogens with anidepressants for depressive disorders: A preclinical review. In Estradiol: Synthesis, Helath Effects and Drugs Interactions; Palmeri, G., Ed.; Nova Science Publishers: New York, NY, USA, 2013.

35. Olivares-Nazario, M.; Fernandez-Guasti, A.; Martinez-Mota, L. Age-related changes in the antidepressant-like effect of desipramine and fluoxetine in the rat forced-swim test. Behav. Pharmacol. 2016, 27, 22-28. [CrossRef] [PubMed]

36. Herrera-Perez, J.J.; Martinez-Mota, L.; Fernandez-Guasti, A. Aging impairs the antidepressant-like response to citalopram in male rats. Eur. J. Pharmacol. 2010, 633, 39-43. [CrossRef] [PubMed]

37. Walf, A.A.; Frye, C.A. Estradiol enhances sociosexual behavior and can have proliferative effects in ovariectomized rats. Age 2009, 31, 221-229. [CrossRef] [PubMed]

38. Hirsh-Rokach, B.; Spectre, G.; Shai, E.; Lotan, A.; Ritter, A.; Al-Aieshy, F.; Malmstrom, R.E.; Varon, D.; Alcalai, R. Differential impact of selective serotonin reuptake inhibitors on platelet response to clopidogrel: A randomized, double-blind, crossover trial. Pharmacotherapy 2015, 35, 140-147. [CrossRef] [PubMed]

39. Hemeryck, A.; Belpaire, F.M. Selective serotonin reuptake inhibitors and cytochrome P-450 mediated drug-drug interactions: An update. Curr. Drug Metabol. 2002, 3, 13-37. [CrossRef]

40. Estrada-Camarena, E.; Fernandez-Guasti, A.; Lopez-Rubalcava, C. Antidepressant-like effect of different estrogenic compounds in the forced swimming test. Neuropsychopharmacology 2003, 28, 830-838. [CrossRef] [PubMed]

41. Olvera-Hernandez, S.; Fernandez-Guasti, A. Sex differences in the burying behavior test in middle-aged rats: Effects of diazepam. Pharmacol. Biochem. Behav. 2011, 99, 532-539. [CrossRef] [PubMed] 
42. VomSaal, F.S.; Finch, C.E.; Nelson, J.F. Chapter 61 Natural history and mechanisms of-Reproductive aging in humans, laboratory rodents, and other selected vertebrates. In The Physiology of Reproduction, 2nd ed.; Knobil, N., Ed.; Raven Press: New York, NY, USA, 1994.

43. Lu, K.H.; Hopper, B.R.; Vargo, T.M.; Yen, S.S. Chronological changes in sex steroid, gonadotropin and prolactin secretions in aging female rats displaying different reproductive states. Biol. Reprod. 1979, 21, 193-203. [CrossRef] [PubMed]

44. Arimoto, J.M.; Wong, A.; Rozovsky, I.; Lin, S.W.; Morgan, T.E.; Finch, C.E. Age increase of estrogen receptor-alpha $(E R \alpha)$ in cortical astrocytes impairs neurotrophic support in male and female rats. Endocrinology 2013, 154, 2101-2113. [CrossRef] [PubMed]

45. Morgan, T.E.; Finch, C.E. Astrocytic estrogen receptors and impaired neurotrophic responses in a rat model of perimenopause. Front. Aging Neurosc. 2015, 7, 179. [CrossRef] [PubMed]

46. Savonenko, A.V.; Markowska, A.L. The cognitive effects of ovariectomy and estrogen replacement are modulated by aging. Neuroscience 2003, 119, 821-830. [CrossRef]

47. Garcia, A.N.; Depena, C.K.; Yin, W.; Gore, A.C. Testing the critical window of estradiol replacement on gene expression of vasopressin, oxytocin, and their receptors, in the hypothalamus of aging female rats. Mol. Cell. Endocrinol. 2016, 419, 102-112. [CrossRef] [PubMed]

48. Flores-Serrano, A.G.; Vila-Luna, M.L.; Alvarez-Cervera, F.J.; Heredia-Lopez, F.J.; Gongora-Alfaro, J.L.; Pineda, J.C. Clinical doses of citalopram or reboxetine differentially modulate passive and active behaviors of female Wistar rats with high or low immobility time in the forced swimming test. Pharmacol. Biochem. Behav. 2013, 110, 89-97. [CrossRef] [PubMed]

49. Chung, S.; Kim, H.J.; Kim, H.J.; Choi, S.H.; Cho, J.H.; Cho, Y.H.; Kim, D.H.; Shin, K.H. Desipramine and citalopram attenuate pretest swim-induced increases in prodynorphin immunoreactivity in the dorsal bed nucleus of the stria terminalis and the lateral division of the central nucleus of the amygdala in the forced swimming test. Neuropeptides 2014, 48, 273-280. [CrossRef] [PubMed]

50. Romano-Torres, M.; Fernandez-Guasti, A. Estradiol valerate elicits antidepressant-like effects in middle-aged female rats under chronic mild stress. Behav. Pharmacol. 2010, 21, 104-211. [CrossRef] [PubMed]

51. Ulloa, R.E.; Diaz-Valderrama, A.; Herrera-Perez, J.; Leon-Olea, M.; Martinez-Mota, L. Age differences in the impact of forced swimming test on serotonin transporter levels in lateral septum and dorsal raphe. Behav. Brain Funct. 2014, 10, 3. [CrossRef] [PubMed]

52. Kakiuchi, T.; Tsukada, H.; Fukumoto, D.; Nishiyama, S. Effects of aging on serotonin transporter availability and its response to fluvoxamine in the living brain: PET study with $\left[{ }^{11} \mathrm{C}\right](+) \mathrm{McN} 5652$ and $\left[{ }^{11} \mathrm{C}\right](-) \mathrm{McN} 5652$ in conscious monkeys. Synapse 2001, 40, 170-179. [CrossRef] [PubMed]

53. Krajnak, K.; Rosewell, K.L.; Duncan, M.J.; Wise, P.M. Aging, estradiol and time of day differentially affect serotonin transporter binding in the central nervous system of female rats. Brain Res. 2003, 14, 87-94. [CrossRef]

54. Ghraf, R.; Michel, M.; Hiemke, C.; Knuppen, R. Competition by monophenolic estrogens and catecholestrogens for high-affinity uptake of $[3 \mathrm{H}](-)$-norepinephrine into synaptosomes from rat cerebral cortex and hypothalamus. Brain Res. 1983, 277, 163-168. [CrossRef]

55. Michel, M.C.; Rother, A.; Hiemke, C.; Ghraf, R. Inhibition of synaptosomal high-affinity uptake of dopamine and serotonin by estrogen agonists and antagonists. Biochem. Pharmacol. 1987, 36, 3175-3180. [CrossRef]

56. Sanchez, M.G.; Estrada-Camarena, E.; Belanger, N.; Morissette, M.; Di Paolo, T. Estradiol modulation of cortical, striatal and raphe nucleus 5-HT1A and 5-HT2A receptors of female hemiparkinsonian monkeys after long-term ovariectomy. Neuropharmacology 2011, 60, 642-652. [CrossRef] [PubMed]

57. Vega-Rivera, N.M.; Lopez-Rubalcava, C.; Estrada-Camarena, E. The antidepressant-like effect of ethynyl estradiol is mediated by both serotonergic and noradrenergic systems in the forced swimming test. Neuroscience 2013, 250, 102-211. [CrossRef] [PubMed]

58. Estrada-Camarena, E.; López-Rubalcava, C.; Fernández-Guasti, A. Facilitating antidepressant-like actions of estrogens are mediated by 5-HT1A and estrogen receptors in the rat forced swimming test. Psychoneuroendocrinology 2006, 31, 905-914. [CrossRef] [PubMed]

59. Estrada-Camarena, E.; Fernández-Guasti, A.; López-Rubalcava, C. Participation of the 5-HT1A receptor in the antidepressant-like effect of estrogens in the forced swimming test. Neuropsychopharmacology 2006, 31, 247-255. [CrossRef] [PubMed] 
60. Page, M.; Detke, M.; Dalvi, A.; Kirby, L.; Lucki, I. Serotonergic mediation of the effects of fluoxetine, but not desipramine, in the rat forced swimming test. Psychopharmacology 1999, 147, 162-167. [CrossRef] [PubMed]

61. Benmansour, S.; Privratsky, A.A.; Adeniji, O.S.; Frazer, A. Signaling mechanisms involved in the acute effects of estradiol on 5-HT clearance. Int. J. Neuropsychopharmacol. 2014, 17, 765-777. [CrossRef] [PubMed]

62. Witty, C.F.; Gardella, L.P.; Perez, M.C.; Daniel, J.M. Short-term estradiol administration in aging ovariectomized rats provides lasting benefits for memory and the hippocampus: A role for insulin-like growth factor-I. Endocrinology 2013, 154, 842-852. [CrossRef] [PubMed]

63. Recamier-Carballo, S.; Estrada-Camarena, E.; Reyes, R.; Fernandez-Guasti, A. Synergistic effect of estradiol and fluoxetine in young adult and middle-aged female rats in two models of experimental depression. Behav. Brain Res. 2012, 233, 351-358. [CrossRef] [PubMed]

64. Bekku, N.; Yoshimura, H. Animal model of menopausal depressive-like state in female mice: Prolongation of immobility time in the forced swimming test following ovariectomy. Psychopharmacology 2005, 183, 300-307. [CrossRef] [PubMed]

65. Okada, M.; Hayashi, N.; Kometani, M.; Nakao, K.; Inukai, T. Influences of ovariectomy and continuous replacement of $17 \beta$-estradiol on the tail skin temperature and behavior in the forced swimming test in rats. Jpn. J. Pharmacol. 1997, 73, 93-96. [CrossRef] [PubMed]

66. Porsolt, R.D.; Le Pichon, M.; Jalfre, M. Depression: A new animal model sensitive to antidepressant treatments. Nature 1977, 266, 730-732. [CrossRef] [PubMed]

67. Detke, M.J.; Rickels, M.; Lucki, I. Active behaviors in the rat forced swimming test differentially produced by serotonergic and noradrenergic antidepressants. Psychopharmacology 1995, 121, 66-72. [CrossRef] [PubMed]

68. López-Rubalcava, C.; Mostalac-Preciado, C.; Estrada-Camarena, E. The rat forced swimming test: An animal model for the study of the antidepressant drugs. In Models of Neuropharmacology; Rocha, L., Granados, V., Eds.; Transworld Res Network: Kenin, India, 2009.

69. Zanardi, R.; Rossini, D.; Magri, L.; Malaguti, A.; Colombo, C.; Smeraldi, E. Response to SSRIs and role of the hormonal therapy in post-menopausal depression. Eur. Neuropsychopharmacol. 2007, 17, 400-405. [CrossRef] [PubMed]

70. Liu, P.Y.; Hoey, K.A.; Mielke, K.L.; Veldhuis, J.D.; Khosla, S. A randomized placebo-controlled trial of short-term graded transdermal estradiol in healthy gonadotropin-releasing hormone agonist-suppressed pre- and postmenopausal women: Effects on serum markers of bone turnover, insulin-like growth factor-I, and osteoclastogenic mediators. J. Clin. Endocrinol. Metabol. 2005, 90, 1953-1960. 